\title{
国際会議 CANDAR 2021 開催報告
}

\author{
中野 浩嗣藤田 聡 \\ 広島大学
}

藤原一毅 鯉㴊 道紘

国立情報学研究所
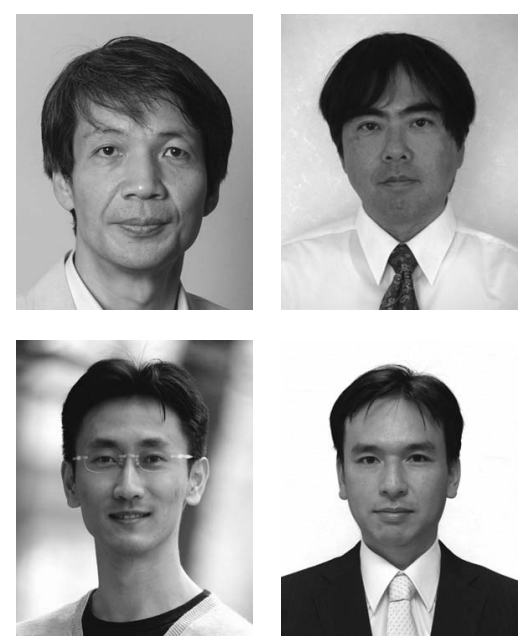

CANDAR (International Symposium on Computing and Networking, http://is-candar.org/) は，コンピューティングとネットワーキングに 関する幅広い分野を扱う国際会議であり，2013 年に第 1 回を松山市で開催して以降, 毎年 11 月 下旬頃に日本国内で開催している. 電子情報通信 学会コンピュータ・システム研究会 $(\mathrm{CPSY})$ の協 賛であり, 論文集はIEEEから出版され, IEEE のデジタルライブラリに収録される，2021年の 第 9 回は松江市で開催の予定であったが，昨年 に引き続き，コロナ禍のため，11月 24〜26 日 の 3 日間の Slack と Zoom を用いたバーチャル 開催となった。

メインシンポジウムは 5 つのトラック (Algorithms and Applications, Architecture and Computer System, Networking and Grid, Artificial Intelligence and Software Engineering, Information and Computer Security) から構成され, 合 計 77 件の投稿があり， 8 件が Long Paper, 20 件が Regular Paper として採択された。採択率 は $36 \%$ あり，質の高い論文が選ばれた。また， 併設の 9 つのワークショップがあり，これらを 含めて合計 121 件の発表があった. 発表の方法 は, (1) 最大 20 分間までの事前録画のプレゼン テーションビデオの作成（インターネットで公
開)，及び (2) 2 枚のスライドによる 5 分間のプ レゼンテーション（Zoom を利用）と質疑応答 を行った。論文 PDF と発表用スライドの公開, 及び，テキストベースのオンラインの質疑応答 には Slackを用いた.オンラインならではの工 夫した開催方法であり，従来のオンサイトでの 開催に比べても, 密度の濃い議論と意見交換が 行えた。

CANDAR2021 では，一般の講演に加え，5件 の基調講演と, GraphGolf ワークショップ, Workshop on Uncertainty-Tolerate Computing using Error-Prone Optical Communication を企画し た。またメインシンポジウム全体で質の高い 論文を 1 件を CANDAR Best Paper，これらに 次いで評価の高い 5 つの論文を CANDAR Outstanding Paper として表彰した. ワークショップ 全体で評価の高い Poster 論文を Workshop Best Poster Paper と Workshop Outstanding Poster Paperに選び，またワークショップ毎に優れた 論文を 1 件ずつ表彰した。

2022 年の CANDAR は 11 月 21 日（月） 24 日（木）に姫路市のアクリエひめじ（姫路市文 化コンベンションセンター）で開催する予定で ある.メインシンポジウムの投稿締め切りは 7 月中旬を予定している. 